\title{
Mecenas Jan Olszewski o projekcie kodeksu karnego Polski Ludowej z 1963 roku
}

\section{Streszczenie}

W pracy przedstawiona została ocena projektu kodeksu karnego Polski Ludowej z 1963 r. dokonana przez Jana Olszewskiego.

Przytoczone argumenty recenzenta doprowadziły autora niniejszego artykułu do wniosku, że krytycyzm Olszewskiego pod adresem projektu dotyczył nie tyle podejścia prawnego czy nawet zastosowanej techniki legislacyjnej, ale przede wszystkim ich konsekwencji ideologicznych i politycznych. Kazuistyka projektu była dla niego bowiem przede wszystkim dowodem wzrostu penalizacji życia oraz nieufności względem stosujących prawo sądów, a nie przejawem troski o ścisłe stosowanie prawa. Nowe typizacje czynów zabronionych, dotyczące rodziny i wolności seksualnej, oceniał z kolei jako wyraz nasilającej się ingerencji władzy w życie prywatne obywateli. Jeśli chodzi natomiast o wizję gospodarki, to rozbudowane przepisy karne $\mathrm{w}$ tym zakresie stanowiły dla niego efekt postępującego „kapitalizmu państwowego”, a nie liberalizacji, której oczekiwał.

Obraz rzeczywistości Polski Ludowej oraz wizja jej przyszłości, ukazane przez pryzmat krytyki dokonanej przez Jana Olszewskiego, pozwoliły na ustalenie rzeczywistego powodu upadku projektu kodeksu karnego z 1963 r., jakim była niewątpliwie jego sprzeczność ideologiczna i polityczna, a nie wady w konstrukcjach prawno-karnych.

Słowa kluczowe: Polska Rzeczpospolita Ludowa, Jan Olszewski, prawo karne, kodeks karny.

\section{Wprowadzenie}

Jan Olszewski, członek Szarych Szeregów, publicysta, działacz opozycyjny, adwokat i prezes Rady Ministrów po 1989 r. ${ }^{1}$ to postać zasłużona dla powojennego ruchu niepodległościowego (Solidarność, Ruch, KOR), zarówno jeśli chodzi

1 A. Friszke, Jan Olszewski, [w:] Słownik polityków polskich XX wieku, red. P. Hauser, S. Żerka, Poznań 1998, s. 253-255. 
o działalność polityczną, jak i tę w charakterze obrońcy w licznych procesach jego członków (m.in. Melchiora Wańkowicza [1964], Jacka Kuronia i Karola Modzelewskiego [1965], Janusza Szpotańskiego [1968], Adama Michnika)². Ideowo Jan Olszewski określał się jako „socjalista niepodległościowy”.

Dla niniejszej pracy postać Jana Olszewskiego jest istotna w kontekście jego udziału w dyskusji nad polskim projektem kodeksu karnego (k.k.) z 1963 r., której skala - jak na warunki Polski Ludowej - była bezprecedensowa ${ }^{4}$. Wystąpienia mecenasa J. Olszewskiego na łamach ówczesnej prasy prawniczej i popularnej wyróżniały się bowiem na tle innych. Nie były one prostą propagandową negacją zaprezentowanych rozwiązań legislacyjnych, ale w sposób kompleksowy, odważny i bezkompromisowy obnażały ich wątpliwą słuszność, tak z prawniczego, jak i przede wszystkim ideologiczno-politycznego punktu widzenia. Zwłaszcza ten ostatni aspekt Jan Olszewski wyraźnie uwypuklał, konfrontując dwie przeciwstawne tendencje socjalistycznego prawa karnego. Pierwszą, przypisywaną Leninowi, zakładającą ograniczoną rolę przymusu w budowie nowego społeczeństwa. Drugą, kojarzoną z Andriejem J. Wyszynskim i okresem „kultu jednostki” - traktującą represję karną jako panaceum na wszelkie braki i dolegliwości społeczne ${ }^{5}$. Wywody Olszewskiego w tym zakresie dowodziły sprzeczności poglądów twórców projektu k.k. z 1963 r. z obowiązującą ówcześnie ideologią, czyli pierwszą tendencją. Co więcej, ukazywały w pełni powody, dla których partia nie mogła dopuścić do uchwalenia kodeksu w przedłożonym kształcie ${ }^{6}$. Zaprezentowanie, do jakich wniosków doszedł Jan Olszewski oraz jak postrzegał obraz Polski Ludowej przez ich pryzmat, jest zadaniem niniejszej pracy.

2 Tamże, s. 254. Zob. także: „Prawnik w czasach bezprawia”. Dyskusja po filmie o Janie Olszewskim, https://portalblogpress.blogspot.com/2017/09/21-sierpnia-gosciem-klubu-ronina-bya. html (dostęp: 19.11.2019).

3 A. Friszke, Jan Olszewski, s. 254.

4 Przykładowo zob. Rozpoczyna się publiczna dyskusja nad projektem nowego kodeksu karnego, „Express Wieczorny” 1963, nr 15, s. 1-2; Projekt nowego kodeksu karnego wchodzi pod publiczną dyskusję, „Trybuna Ludu” 1963, nr 18, s. 3; M. Jankowski, Przed publiczna dyskusją. Nad projektem kodeksu karnego, „Słowo Ludu” 1963, nr 73, s. 3; J. Kolczyński, Projekt kodeksu karnego. Sześć pytań, „Prawo i Życie” 1963, nr 2, s. 1; Kodeks karny w ogniu dyskusji, „Polityka” 1963, nr 13, s. 4; Projekt nowego kodeksu karnego. Postulat zniesienia kary dożywotniego więzienia, „Gazeta Krakowska” 1963, nr 16, s. 2; Krok naprzód czy wstecz?, „Głos Wielkopolski" 1963, nr 59, s. 3-4; E. Goździcki, Dyskutujemy nad proj. kk - Czy to logiczne?, „Wieczór” 1963, nr 44, s. 4; S. Reperowicz, Obywatel w cieniu paragrafów, „Żołnierz Wolności” 1963, nr 61, s. 3; W. Podsiadło, Nad projektem kodeksu karnego (2) - paragrafy i życie, „Głos Szczeciński” 1963, nr 86, s. 3; A. Weiser, Bezkarność przekupstwa w projekcie kodeksu karnego, „Głos Robotniczy” 1963, nr 115, s. 3.

5 Wielka kariera małej książeczki, „Nowa Kultura” 1963, nr 9, s. 2.

6 J. Kochanowski, Redukcja odpowiedzialności karnej: analiza i ocena założeń Kodeksu karnego z 1997 r. na tle innych polskich kodyfikacji karnych, Warszawa 2000, s. 9. 
Pierwszy zarzut Jana Olszewskiego pod adresem autorów projektu dotyczył właśnie przecenienia roli represji karnej w procesach przekształceń społeczno-gospodarczych państwa socjalistycznego. Projektodawcy wychodzili bowiem z założenia, że postępująca po wojnie rewolucja wymagała nie tyle ograniczania przepisów prawa karnego, co wręcz tworzenia nowych typizacji części szczególnej oraz rozbudowania tych już istniejących dla ochrony przed nieznanymi do tej pory rodzajami zamachów ${ }^{7}$. Dla Olszewskiego takie podejście było nie do przyjęcia, albowiem z jednej strony zaprzeczało Leninowskiej nauce o wpływie represji karnej na budownictwo państwa socjalistycznego, a z drugiej - stanowiło jaskrawy przejaw hołdowania krytykowanej koncepcji „Akademika Wyszynskiego” głoszącej, że represja karna jest panaceum na wszelkie dolegliwości społeczne. Jak podkreślał Olszewski, przy takim ujęciu prawo karne „[...] ze środka koniecznej ochrony przeobraża się w uniwersalny środek wychowawczy, nie tyle przestępców, ile całego społeczeństwa, któremu polityka nasilonych represji ma wpoić nowe zasady społecznego postępowania"s.

Jego zdaniem takie podejście pozostawało również w sprzeczności z aktualnie przyjętymi rozwiązaniami nowego radzieckiego kodeksu karnego ${ }^{9}$. Ten zarzut w konsekwencji oznaczał, że polska kodyfikacja co najmniej nie nadążała za trendami prawnymi w ojczyźnie rewolucji proletariackiej, a nawet - co gorsza - zdawała się je ignorować ${ }^{10}$.

Co jednak zdaniem Olszewskiego stanowiło o zbliżeniu projektu do koncepcji Wyszynskiego? Przede wszystkim wyraźna tendencja do penalizacji życia, przejawiająca się w znacznej liczbie nowych czynów zabronionych stypizowanych w części szczególnej projektu, których Olszewski doliczył się aż 50. Część z nich omówił $\mathrm{z}$ nieskrywaną ironią. I tak, przepis art. $283^{11}$ dotyczący karalności podmieniania niemowląt w zakładach położniczych skomentował stwierdzeniem: „[...] sąd karny został obciążony troską, by pielęgniarki nie zamieniały dzieci” ${ }^{12}$. Podobnie,

7 Ze wstępu do projektu: „Postępująca urbanizacja i wielkie migracje wewnętrzne pociągnęty za sobą osłabienie, a nawet zerwanie więzów rodzinnych i powiązań gromadzkich. Musiało to doprowadzić do rozluźnienia dawnych form kontroli społecznej. Aktualny staje się więc problem znalezienia nowych form ochrony społeczeństwa przed zamachami" - Wstęp do projektu kodeksu karnego, s. II, [w:] Projekt kodeksu karnego, Warszawa 1963 [dalej: Projekt k.k. z 1963 roku...].

8 J. Olszewski, Zasady kodeksu i logika życia, „Prawo i Życie” 1963, nr 3, s. 1.

9 Tamże.

10 H.J. Berman, Principles of Soviet Criminal Law, „Yale Law Journal” 1947, t. 56, s. 822-823, https://digitalcommons.law.yale.edu/ylj/vol56/iss5/2S (dostęp: 12.11.2019).

11 „Pracownik zakładu położniczego, który z winy nieumyślnej powoduje zamianę dziecka, na skutek czego następuje zmiana jego tożsamości, podlega karze pozbawienia wolności do roku lub grzywny" - Projekt k.k. z 1963 roku..., s. 58.

12 J. Olszewski, Zasady kodeksu..., s. 1. 
jeśli chodzi o wymóg należytej sprawności fizycznej i psychicznej kierowców (art. $251^{13}$ ) oraz ochronę zwierząt przed okrucieństwem ludzkim (art. $426^{14}$ ).

$\mathrm{O}$ ile jednak powyższe propozycje były dla niego zaskoczeniem i jako takie zasłużyły na zwykłą ironię, o tyle inaczej było w przypadku przepisów dotyczących szeroko pojętych stosunków rodzinnych. W tym zakresie Jan Olszewski nie tylko posłużył się ironią właściwą dla tekstów publicystycznych, ale ponadto dał wyraz wręcz osobistego oburzenia tym faktem. Projekt kodeksu przewidywał bowiem trzy istotne nowości, dotykające bardzo osobistych, a wręcz intymnych kwestii. Pierwszą stanowił stypizowany w art. 289 występek narażenia na niemożność zaspokojenia podstawowych potrzeb życiowych na skutek przepijania, hazardu lub innego trwonienia mienia ${ }^{15}$. Drugą był art. 290 penalizujący czyn polegający na dopuszczeniu do wykolejenia społecznego małoletniego ${ }^{16}$. Trzecią był art. $273 \$ 2$ dotyczący czynu polegającego na zaspokojeniu popędu płciowego z osobą całkowicie lub w znacznym stopniu pozbawioną zdolności rozpoznania znaczenia czynu lub pokierowania swym postępowaniem ${ }^{17}$. Olszewski domyślał się, że projektodawcom chodzi o kwestię stosunków płciowych w stanie nietrzeźwości oraz ich ewentualne konsekwencje z punktu widzenia eugeniki. Jego zdaniem jednak, wobec powszechnej praktyki spożywania alkoholu przez osoby obojga płci w tego typu sytuacjach, działania kodyfikatorów zaszły zbyt daleko ${ }^{18}$. Co więcej, o ile za „rozsądne” uznał wyłączenie odpowiedzialności karnej małżonków, o tyle nie był w stanie zrozumieć, dlaczego „[...] zaspokojenie popędu płciowego nieusankcjonowane sakramentem w aktach stanu cywilnego" miałoby być karalne ${ }^{19}$.

13 „Kierowca, który prowadzi pojazd mechaniczny, będąc do tego niezdatny fizycznie lub psychicznie albo nie mając do tego wymaganych uprawnień, podlega karze pozbawienia wolności do lat 2 lub grzywny (\$1). Usiłowanie jest karalne (\$2) - Projekt k.k. z 1963 roku..., s. 50.

14 „Kto znęca się nad zwierzęciem, podlega karze pozbawienia wolności do roku lub grzywny” - tamże, s. 86.

15 „Kto przepija, wydaje na gry hazardowe lub w inny sposób trwoni lub wyzbywa się albo niszczy mienie, które powinno służyć zaspokojeniu potrzeb dzieci, małżonka lub wspólnie zamieszkałych ze sprawcą innych osób najbliższych, i przez to, chociażby z winy nieumyślnej, naraża je na niemożność zaspokojenia podstawowych potrzeb życiowych, podlega karze pozbawienia wolności do lat 3" (art. 289) - tamże, s. 59.

16 „Kto względem małoletniego nie wykonuje obowiązków wynikających z władzy rodzicielskiej, opieki lub nadzoru powierzonego przez właściwy organ i przez to, chociażby z winy nieumyślnej, dopuszcza do wykolejenia społecznego małoletniego, podlega karze pozbawienia wolności do lat 2 lub grzywny” (art. 290) - tamże.

17 „Kto zaspokaja popęd płciowy z osobą, która nie ukończyła lat 15, podlega karze pozbawienia wolności od roku do lat 10 (§1). Tej samej karze podlega, kto zaspokaja popęd ptciowy z osobą całkowicie lub w znacznym stopniu pozbawioną zdolności rozpoznania znaczenia czynu lub kierowania swym postępowaniem (\$2) - tamże.

18 J. Olszewski, K.k. i fantazja, „Nowa Kultura” 1963, nr 11, s. 3.

19 Tamże. 
Olszewski skwitował te rozwiązania w następujący sposób:

Przy przyjęciu wykładni najbardziej dosłownej - a nie ma logicznych podstaw, aby ją odrzucić - stałym gościem naszych domów rodzinnych staje się prokurator występujący w całym majestacie nowego kodeksu. Pełni on zarazem funkcje kontrolera budżetów domowych i guwernantki czuwającej nad prawidłowym wychowaniem dzieci. [...] staje się nie tylko nadzorcą małżeńskiego stołu, ale i łoża. Z woli kodyfikatorów winien czuwać, czy małżonkowie przestrzegają w grze miłosnej zasad współżycia społecznego, obowiązujących w Państwie Ludowym. Wydaje się, że dalej na drodze penalizacji stosunków międzyludzkich już się posunąć nie można. Nie można również twierdzić, aby twórcy projektu k.k. osiągnęli w swych zamierzeniach granicę absurdu. Te granice zostały bowiem daleko przekroczone ${ }^{20}$.

Dla mecenasa Olszewskiego nieakceptowalne było nie tylko wkraczanie sądu, prokuratury i przepisów prawa karnego w nawet najintymniejsze stosunki społeczne czy rodzinne, ale również wizja przyszłości, jaką zaprezentowano w przepisach projektu. Zaostrzenie sankcji oraz wzrost penalizacji życia poprzez wprowadzenie nowych czynów zabronionych były dla Olszewskiego sygnałem, że przyszłość owa w umysłach kodyfikatorów jawiła się nader ponuro, a w konsekwencji sprzecznie z jej ideologicznie poprawnym obrazem.

Przede wszystkim prawnik za kontrowersyjne uznał wprowadzenie do projektu obszernego działu przestępstw wojennych. Jego zdziwienie wywołały rozbudowane normy dotyczące pogwałcenia zasad i zwyczajów prowadzenia wojny, dla których miejsce widział przede wszystkim w konwencjach międzynarodowych. Olszewskiego zdumiał także obszerny katalog przestępstw przeciwko państwu. To pierwsze świadczyło jego zdaniem o wizji zbliżającego się kataklizmu wojennego, choć oznaczałaby ona zagrożenie dla istnienia cywilizacji ludzkiej, to drugie z kolei - o niewystarczającej skuteczności dotychczasowych przepisów, które w opinii publicysty „[... [ okazały się zupełnie wystarczającą bronią w okresie, gdy państwo było atakowane wprost przez podziemie polityczne, w okresie, gdy w kraju istniały warunki zbliżone do wojny domowej”21. Zapewne chodziło o przepisy m.k.k ${ }^{22}$. oraz kodeksu karnego Wojska Polskiego ${ }^{23}$.

Nie tyle jednak wizja nowej wojny światowej była dla Olszewskiego absurdalna czy wręcz „fantazyjna”, co przede wszystkim obraz przyszłych stosunków wewnętrznych w Polsce Ludowej. Z podwyższenia sankcji karnej za przestępstwo

20 J. Olszewski, Zasady kodeksu..., s. 3.

21 J. Olszewski, K.k. i fantazja, s. 1.

22 Dekret z 13 czerwca 1946 r. o przestępstwach szczególnie niebezpiecznych w okresie odbudowy państwa (Dz.U. Nr 30 poz. 192). Pierwsza wersja wydana została 16 listopada 1945 r. (Dz.U. Nr 53 poz. 300). Szerzej zob. A. Lityński, O prawie i sądach początków Polski Ludowej, Białystok 1999, s. 101-111.

23 Dz.U. z 1944 r. Nr 6 poz. 27; zob. A. Lityński, O prawie i sqqdach..., s. 72-77. 
szerzenia pogardy i nienawiści rasowej i narodowościowej (art. 16024) oraz rozszerzenia katalogu czynów zabronionych przeciwko wolności sumienia i wyznania (Rozdział XIX, art. 175-181) wnioskował, że projektodawcy przewidują „nasilenie waśni narodowościowych i religijnych" ${ }^{25}$. Jego zdaniem rzeczywistość podważała tę wizję. Jak bowiem stwierdził,

[...] nie ma dziś w Polsce poważniejszych mniejszości narodowych. Fanatyzm religijny znajduje się w oczywistym odwrocie. W pokoleniu ludzi dziś trzydziesto- lub dwudziestoletnich kwestia przekonań religijnych lub ich braku z pewnością nie jest najistotniejszym problemem [...]. Powszechny postęp oświaty wypiera coraz bardziej ciemnotę i nic nie wskazuje na to, aby w przyszłości proces ten miał ulec opóźnieniu czy wręcz odwróceniu. Skąd więc ta apokaliptyczna wizja społeczeństwa rozdzieranego konfliktami przeniesionymi w naszą epokę jak gdyby wprost ze średniowiecza?26

Odpowiedź na tak zadane pytania nasuwała się sama po przeczytaniu art. $175^{27}$ i art. $177^{28}$. Przepisy te były reakcją na narastający konflikt między wierzącymi a niewierzącymi, kojarzonymi z partią rządzącą. Co więcej, art. $180^{29}$ projektu wskazywał, że choć od uchwalenia „dekretu sierpniowego” ${ }^{30}$ minęło niemal 15 lat, to o odejściu od konfrontacji z hierarchami kościelnymi nie było mowy. I to właśnie niepokoiło Olszewskiego, który dostrzegał w projekcie tendencję do zaostrzania walki z Kościołem i osobami wierzącymi, a w konsekwencji wzmagania się antagonizmów społecznych.

24 „Kto szerzy pogardę lub nienawiść do grupy narodowej, etnicznej, rasowej lub wyznaniowej albo ją lży, wyszydza lub poniża, podlega karze pozbawienia wolności od 6 miesięcy do lat 8" - Projekt k.k. z 1963 roku..., s. 34.

25 J. Olszewski, K.k. i fantazja, s. 1.

26 Tamże.

27 „Kto z powodu przekonań innej osoby w sprawach religii, jej przynależności wyznaniowej lub bezwyznaniowości stosuje wobec tej osoby lub jej bliskiego dyskryminację, w szczególności przez to, że odmawia wykonania czynności, do której jest zobowiązany, zwleka z jej wykonaniem lub przy jej wykonaniu daje pierwszeństwo innym osobom, podlega karze pozbawienia wolności do lat 3" - Projekt k.k. z 1963 roku..., s. 36.

28 „Kto przemocą lub groźbą albo przez wyzyskanie stosunku zależności, organizowanie lub namawianie do bojkotu społecznego bądź w inny podobny sposób zmusza inną osobę do udziału w czynności lub obrzędzie religijnym, podlega karze pozbawienia wolności do lat 5" - tamże.

29 „Kto, pełniąc funkcję religijną, nadużywa wolności sumienia i wyznania przez to, że w czasie publicznego obrzędu religijnego: - znieważa lub wyszydza Naród Polski, Państwo Polskie lub ustrój Polskiej Rzeczypospolitej Ludowej, - rozgłasza wiadomości nieprawdziwe mogące wywołać niepokój publiczny lub wyrządzić inną istotną szkodę interesowi publicznemu, - nawołuje do nieposłuszeństwa lub przeciwdziałania ustawie albo rozporządzeniu, zarządzeniu lub uchwale organu władzy lub administracji państwowej, wydanych na podstawie ustawy i w jej wykonaniu, - nawołuje do przestępstwa lub je pochwala, podlega karze pozbawienia wolności od roku do lat 10" - tamże, s. 37.

30 Dekret z dnia 5 sierpnia 1949 r. o ochronie wolności sumienia i wyznania (Dz.U z 1949 r. Nr 45 poz. 334). 
$\mathrm{Na}$ te argumenty Jana Olszewskiego powoływał się również Episkopat Polski, który za pośrednictwem swojego sekretarza biskupa Zygmunta Choromańskiego $^{31}$, w piśmie z 9 maja 1963 r., wyraził swoją negatywną opinię o projekcie ${ }^{32}$.

Dramatycznie - zdaniem Olszewskiego - wyglądała również wizja gospodarki w przepisach projektu (Rozdział XXVII, art. 311-328). Kazuistyczne przepisy dotyczące m.in. brakoróbstwa w zakresie produkcji, budownictwa i usług remontowych (art. 320 33), tzw. bubloróbstwa (art. 319 ${ }^{34}$ ) i niesumiennej sprawozdawczości (art. 323 $3^{35}$ ) świadczyły jego zdaniem o „[...] nawrocie w kierunku wzorów modelowych komunizmu wojennego" ${ }^{36}$. To w konsekwencji oznaczało według niego ewidentną sprzeczność rozwiązań projektu z prognozami przedstawianymi przez ekonomistów i planistów, które zakładały m.in. zastępowanie administracyjnych metod kierowania gospodarką systemem bodźców ekonomicznych, a przez to usamodzielnianie się przedsiębiorstw i ich decentralizację $e^{37}$.

Rozbudowany katalog przestępstw związanych z gospodarką przeczył powyższej wizji. Z kolei fakt pominięcia w projekcie przepisów ustawy z dnia 21 stycznia 1958 r. o wzmożeniu ochrony mienia społecznego przed szkodami wynikającymi z przestępstwa ${ }^{38}$ był zdaniem Olszewskiego przejawem nieuzasadnionego optymizmu, jeśli chodzi o likwidację tzw. przestępczości aferowej, którą kodyfikatorzy

31 Jeden z trzech sygnatariuszy porozumienia „O niektórych warunkach życia i działalności Kościoła katolickiego w Polsce” podpisanego 14 kwietnia 1950 r. przez przedstawicieli Kościoła katolickiego i władze komunistyczne - A. Nowicz, Stosunki Kościót-państwo w Polsce 1944-1956 (szkic zagadnienia), Poznań 1984, s. 40-41.

32 Pismo Sekretarza Episkopatu Polski biskupa Zygmunta Choromańskiego z dnia 9 maja 1963 r. do ministra sprawiedliwości Mariana Rybickiego w sprawie uwag do projektu kodeksu karnego, s. 2 (Archiwum Akt Nowych, Ministerstwo Sprawiedliwości, sygn. 564).

33 „Kierownik robót budowlanych lub remontowych albo inna osoba odpowiedzialna za jakość wykonania takich robót lub za ich przyjęcie, która powoduje oddanie jako gotowego do użytku budynku lub lokalu albo instalacji lub urządzenia służącego do ich eksploatacji, mimo że znajdują się one w stanie niezdatnym do użytku albo mimo że jakość wykonanych robót jest rażąco niższa od wymaganej, podlega karze pozbawienia wolności do lat 5" - Projekt k.k. z 1963 roku..., s. 65.

34 „Kierownik zakładu wytwórczego albo inna osoba odpowiedzialna za produkcję lub za kontrolę jakości produkcji, jak również kierownik instytucji handlowej lub inna osoba odpowiedzialna za jakość towaru, która wprowadza do obrotu, zbywa lub dostarcza wyroby lub inne towary nie nadające się do użytku zgodnie z przeznaczeniem lub o jakości rażąco niższej od ustalonej przez właściwe organy, podlega karze pozbawienia wolności do lat 5" - tamże, s. 64.

35 „Pracownik instytucji państwowej lub społecznej, który w sprawozdaniu, wykazie lub zestawieniu, przeznaczonym dla instytucji nadrzędnej, nadzorującej, kontrolującej lub finansującej albo ustalającej lub zatwierdzającej ceny lub normy, zamieszcza dane nieprawdziwe, jeżeli to mogło wywołać istotną szkodę gospodarczą, podlega karze pozbawienia wolności do lat 5" - tamże, s. 65.

36 J. Olszewski, K.K. i fantazja, s. 2.

37 Tamże.

38 Dz.U z 1958 r. Nr 4 poz. 11. 
postrzegali jako zjawisko przejściowe ${ }^{39}$. W związku z tym retorycznie zapytał: „Jeśli zatem na tym odcinku perspektywa przyszłości przedstawia się tak dobrze, dlaczego ma być tak źle, gdy chodzi o wszystkie pozostałe rodzaje przestępstw?"

Dla mecenasa Jana Olszewskiego trudna do zaakceptowania była nie tylko penalizacja, przejawiająca się wzrostem liczby nowych czynów zabronionych, ale również stanowiąca jej konsekwencję technika legislacyjna, polegająca na zerwaniu z metodą syntetyczną na rzecz kazuistycznej ${ }^{41}$. Wręcz szokujące dla niego było uzasadnienie projektodawców, wedle którego metoda syntetyczna była wadliwa, albowiem „[...] nadmiernie przesuwała ciężar dostosowania przepisów do życia z ustawodawcy na sędziów” oraz sprawiała trudności „[...] sędziom z mniejszym wykształceniem i mniejszą praktyką" ${ }^{\prime 2}$. Był to dla niego jaskrawy dowód na swoiste wotum nieufności w stosunku do kadry sędziowskiej i to nie tylko tej ówczesnej, ale przede wszystkim tej mającej stosować kodeks w przyszłości. Jego zdaniem nie było podstaw, aby zakładać, że przez cały okres obowiązywania przyszłego kodeksu sędziów w Polsce będzie cechował brak należytego wykształcenia oraz słabe przygotowanie praktyczne. Co więcej, podkreślał, że jeżeli tak źle prezentuje się perspektywa kadr prawniczych PRL, to twórcy projektu - w większości profesorowie i wykładowcy wydziałów prawa ${ }^{43}$ - sami sobie wystawiają negatywną ocenę jako dydaktycy odpowiedzialni za kształcenie młodych prawników ${ }^{44}$.

Olszewski nie akceptował również twierdzenia, że większa szczegółowość norm karnych sprzyja kształtowaniu świadomości ogółu obywateli, a więc spełnia rolę wychowawczą lepiej niż metoda syntetyczna. Według niego to przekonanie oparte było na błędnym założeniu, że kodeks karny stanie się „[...] lekturą używaną do poduszki", a samo wydanie przepisów karnych - a nie ich stosowanie - będzie oddziaływało wychowawczo na stosunek obywateli do Państwa Ludowego, własności społecznej czy innych współobywateli. Zdaniem Olszewskiego projektodawcy zapomnieli, że kodeks karny pisze się dla przestępców, a nie dla narodu. Powołując

39 J. Olszewski, Zasady kodeksu..., s. 3.

40 Tamże.

41 J. Olszewski, Rozprawa z metodq, „Prawo i Życie” 1963, nr 4, s. 3.

42 Tamże.

43 W skład Zespołu Prawa Karnego Materialnego Komisji Kodyfikacyjnej weszli: I. Andrejew, T. Cyprian, A. Gubiński, H. Holder, L. Lernell, J. Potępa, J. Sawicki, M. Szerer (przewodniczący), W. Winawer i W. Wolter. Jako delegat ministra sprawiedliwości w obradach uczestniczył J. Bafia, a delegatem Prokuratora Generalnego PRL był H. Rajzman. Sprawozdawcami catości projektu byli J. Sawicki i W. Winawer - Projekt k.k. z 1963 roku..., s. III; L. Tyszkiewicz, Projekt kodeksu karnego z 1963 roku na tle ewolucji polskiego prawa karnego w XX wieku, [w:] O prawie i jego dziejach księgi dwie. Studia ofiarowane profesorowi Adamowi Lityńskiemu w czterdziestopięciolecie pracy naukowej i siedemdziesięciolecie urodzin, ks. II, red. M. Mikotajczyk i in., Białystok-Katowice 2010, s. 726-727.

44 J. Olszewski, Rozprawa... 
się na poglądy Mieczysława Szerera, prawnik podkreślił, że nawet w samym gronie autorów projektu nie było w tym względzie jednomyślności ${ }^{45}$.

Krytyka metody kazuistycznej ze strony Jana Olszewskiego objęła również argument, że ma ona rzekomo umacniać fundamentalne zasady nullum crimen sine lege i nulla poena sine lege. Dla późniejszego premiera polskiego rządu takie postawienie sprawy było również fałszywe, albowiem sugerowało, jakoby problem ten sprowadzał się do wyboru pomiędzy kazuistyczną a syntetyczną budową kodeksu. Jego zdaniem kluczowe było bowiem to, jakich elementów używa się do formułowania znamion czynu przestępnego, a więc opisowych czy normatywnych. To właśnie te ostatnie, jako podlegające ocenie nie z punktu widzenia obiektywnych faktów, a subiektywnych przekonań sędziego, stanowiły jego zdaniem o wadliwości projektu ${ }^{46}$. Jak bowiem zaznaczył, „[...] obserwujemy prawdziwą inflację znamion ocennych, które podważają stabilność i zacierają ostrość granic projektowanych przepisów, [...] obserwujemy istną inwazję "stanów niebezpieczeństwa«, które nadają przepisom kodeksu cechy płynności i groźnej rozciągliwości interpretacyjnej” ${ }^{37}$. Olszewski pytał wprost: „Komu to jest potrzebne w społeczeństwie, które bardzo umocnienia praworządności pragnie? Qui bono?”48.

Według Olszewskiego język projektu także stanowił o jego wadliwości. Określił go wręcz mianem „barokowego”. Ironicznie zarzucił twórcom, że gdyby to tylko było możliwe, to napisaliby go heksametrem ${ }^{49}$. Jako „reprezentantów” tej rozwlekłości i zbędnego ozdobnictwa wskazał art. $127^{50}$ oraz preambułę ${ }^{51}$. Jego zdaniem to samo można by osiągnąć przy znacznie bardziej ograniczonym zasobie słów,

45 „Kodeks karny nie jest jakimś vademecum obywatela, nie jest podręcznikiem, który by nosił on przy sobie i co rusz do niego zaglądat. Nie kodeks karny kształci też moralność członków społeczeństwa - ten cel osiąga się pozytywnymi środkami wychowawczymi, a nie zakazami i groźbami przepisów karnych" - cyt. za: J. Olszewski, Rozprawa..., s. 3; zob. także: M. Szerer, Punkty wyjścia, „Życie Warszawy” 1962, nr 290, s. 3; tenże, Z części szczególnej sprawy szczególnie ważne, „Życie Warszawy” 1962, nr 295, s. 3.

46 J. Olszewski, Rozprawa..., s. 3.

47 Tamże, s. 4.

48 Tamże; Wielka kariera..., s. 2.

49 J. Olszewski, K.k. i fantazja, s. 3.

50 „Kto w celu osłabienia władzy ludowej, a w szczególności w celu wywołania zaburzeń lub nastrojów powszechnego niezadowolenia albo zakłóceń w zaopatrzeniu ludności, niszczy, uszkadza lub w inny sposób czyni niezdatnymi do użytku kopalnie, zakłady, budowle lub urządzenia przemysłowe, drogi, środki komunikacji lub łączności, zakłady lub urządzenia użyteczności publicznej, budowle lub urządzenia przemysłowe, drogi, środki komunikacji lub łączności, zakłady lub urządzenia użyteczności publicznej, budowle lub urządzenia obronne albo inne mienie społeczne o poważnym znaczeniu dla interesów państwa, podlega karze pozbawienia wolności na czas nie krótszy od lat 5 lub karze śmierci” - Projekt k.k. z 1963 roku..., s. 27.

51 „Kodeks karny służy ochronie: niezawisłości Polskiej Rzeczypospolitej Ludowej i nienaruszalności jej granic, socjalistycznego ustroju Polskiej Rzeczypospolitej Ludowej i ustanowionego w niej porządku prawnego - własności społecznej - osób i ich praw. W tym celu kodeks karny 
a w konsekwencji bardziej przejrzystym układzie ${ }^{52}$. Jeśli bowiem chodzi o preambułę, to ironicznie stwierdził, że „[a]utorzy tej preambuły nie zauważyli najwidoczniej, że w pojęciu ochrony ustanowionego w PRL porządku prawnego mieści się także ochrona własności społecznej, osób i ich praw i wiele jeszcze innych rzeczy”53. Z kolei odnośnie do art. 127 za wystarczającą uznał konstrukcję: „Kto w celu osłabienia władzy ludowej czyni niezdatnym do użytku mienie społeczne o poważnym znaczeniu dla interesów państwa, podlega karze..." ${ }^{34}$.

Powyższe argumenty pozwoliły Olszewskiemu na postawienie projektodawcom zarzutu niekonsekwencji i sprzeczności w formułowaniu haseł mających uzasadnić przygotowane propozycje legislacyjne. Prawnik trafnie bowiem zauważył, że autorzy $\mathrm{z}$ jednej strony sugerowali wątpliwą jakość merytoryczną aktualnych i przyszłych kadr sądów i prokuratur, a z drugiej, za sprawą znamion normatywnych wielu przepisów, to właśnie im polecali ich doprecyzowanie ${ }^{55}$. Lecz wykazana tym samym ewidentna sprzeczność logiczna formułowanych argumentów nie była punktem najistotniejszym. Była nim za to wyraźna „niedojrzałośc” polityczna i ideologiczna twórców, która - niezależnie od ewentualnej intencji - dyskwalifikowała ich dzieło.

\section{Zakończenie}

Jak mawiał Juliusz Makarewicz,

[...] dla poznania rzeczywistego charakteru danego społeczeństwa, jego pojęć moralnych, jego zasad gospodarczych, jego ustroju państwowego konieczne jest zapoznanie się z jego kodeksem karnym. W tym, za co się karze i jak się karze, a także w tym, czego się nie karze, odbija się całe życie danego społeczeństwa ${ }^{56}$.

określa, jakie czyny społecznie niebezpieczne stanowią przestępstwa, i ustanawia za nie kary" - Projekt k.k. z 1963 roku..., s. 1.

52 J. Olszewski, K.k. i fantazja, s. 3.

53 Tamże.

54 Tamże.

55 Tamże.

56 Kodeks karny republik sowieckich, przeł. R. Łemkin, T. Kochanowicz przy współudz. L. Dworzaka, Z. Papierkowskiego, R. Piotrowskiego, wstęp J. Makarewicz, Warszawa 1927, s. 7. Myśl tę przypomniał Stefan Kalinowski w trakcie wstępnych prac nad kodyfikacją prawa karnego w 1947 r. - zob. S. Kalinowski, Uwagi dotyczq̨ce systematyki części szczególnej kodeksu karnego, s. 6 (Archiwum Akt Nowych w Warszawie, Ministerstwo Sprawiedliwości, sygn. 285/1941). 
Prawo karne jest „[...] jak gdyby fotografią ustroju politycznego i stosunków społecznych panujących w danej chwili, w danym społeczeństwie. Jest to po prostu dokładny negatyw fotograficzny, odbijający rzeczywistośćn ${ }^{57}$.

Według Jana Olszewskiego ten obraz teraźniejszości i przyszłości Polski Ludowej w projekcie z 1963 r. to

[...] obraz społeczeństwa zagrożonego ustawicznym niebezpieczeństwem zewnętrznej napaści, gnębionego przy tym narastającymi konfliktami wewnętrznymi, którego gospodarka jest stotalizowana tak dalece, że jej najważniejszym spoiwem staje się nakaz normy prawnej, a głównym bodźcem obawa przed odpowiedzialnością sądową. Jest to obraz przyszłości najdokładniej przeciwny temu, czego mamy prawo oczekiwaćs ${ }^{58}$.

Jak to obrazowo wyraził na łamach „Nowej Kultury”, „[...] nowa kodyfikacja jest w swych założeniach ideologicznych spóźniona o lat co najmniej 10, w ocenie rzeczywistości społecznej i gospodarczej i jej perspektyw rozwojowych o lat 50, a w zastosowanej technice legislacyjnej o lat niemal 150 "59.

Projekt z 1963 r. stanowił dla Olszewskiego wielkie rozczarowanie, także dlatego, że opierał się w jego ocenie na projekcie z 1956 r., który miał hołdować potępianej tezie o zaostrzaniu się walki klasowej w miarę budowy ustroju socjalistycznego ${ }^{60}$.

Trudno się dziwić rozgoryczeniu Jana Olszewskiego. Propaganda tamtego okresu karmiła ludzi perspektywą wszechogarniającego postępu na drodze do socjalizmu. W praktyce jednak nic się nie zmieniało, a represje oraz wszechwładność prawa karnego jako instrumentu utrzymującego ten system w ryzach nie słabły. Wypada zatem zapytać, kto miał rację: twórcy projektu czy Jan Olszewski? Ci pierwsi, realnie oceniając rzeczywistość i przyszłość, czy Olszewski jako „socjalista niepodległościowy”, który oczekiwał, że w projekcie znajdzie odbicie nie tyle teraźniejszość, co właśnie oczekiwana i ideologicznie poprawna przyszłość? Odpowiedź na to pytanie zależy od momentu jej udzielania. Obecnie oczywiście to podejście zespołu kodyfikacyjnego prof. Jerzego Sawickiego należałoby ocenić jako prawidłowe, z kolei odpowiadając z perspektywy 1963 r., rację miał Olszewski. Socjalistyczny kodeks karny miał „programować” wyidealizowaną perspektywę przyszłości. Pomijać drażliwe problemy społeczne i polityczne teraźniejszości lub nie eksponować ich. Nie obnażać słabości społeczno-gospodarczo-politycznej państwa, a taką niewątpliwie była próba reagowania na patologie w drodze represji karnej.

Pokazuje to, w jak trudnej sytuacji byli ówcześni projektodawcy. Przyszłości przecież nie znali, a rzeczywistości zakłamywać nie chcieli. Jak trafnie bowiem

57 S. Pławski, Walka Makarewicza o praworzq̨dność, „Państwo i Prawo” 1966, z. 2, s. 239.

58 J. Olszewski, K.K. i fantazja, s. 1.

59 Tamże, s. 3.

60 J. Olszewski, K.k. i fantazja, s. 2; szerzej na temat projektu z 1956 r. zob. J. Olszewski, Projekt nowy - treść stara, „Po prostu” 1956, nr 22, s. 2. 
zauważył Leon Tyszkiewicz, „[...] rozbudowa części szczególnej nie była wynikiem tendencji do zwiększania ingerencji prawa karnego w życie społeczne, ale miała swoje korzenie w dążeniu do usunięcia możliwych luk i zachowania pełnej konsekwencji w realizowaniu polityki kryminalizacyjnej"61.

Recenzja projektu autorstwa Jana Olszewskiego była jednak dowodem na to, że na jego odbiorze zaważyła ideologia. Jego krytyka - niezależnie od intencji autorów - obnażyła niewątpliwie sprzeczność dwóch wyobrażeń rzeczywistości i przyszłości. Pierwszego, którego odbicie stanowiły przepisy projektu. Drugiego, który był oczekiwany politycznie i akceptowany ideologicznie. Oczywiście, ulec miały nie ideologia ani propaganda, a właśnie projekt, który musiał upaśćc ${ }^{2}$. Kolejna wersja miała już tego rodzaju błędów nie powielać. Co więcej, w losach „projektu Sawickiego" i dyskusji stanowiącej ich element znajduje potwierdzenie teza o generalnym zakłamywaniu w tym systemie politycznym nie tylko rzeczywistości, lecz także przyszłości. Olszewski dostrzegł i pokazał przez pryzmat tego projektu obraz Polski Ludowej, którego nikt nie chciał oglądać, ani aktualnie, ani w przyszłości. Tego rodzaju podejście odbiło się na negatywnym stosunku przyszłego premiera do tej propozycji legislacyjnej, choć pozytywnych i nowatorskich rozwiązań - zwłaszcza w części ogólnej - nie brakowało ${ }^{63}$.

\section{Bibliografia}

\section{Źródta archiwalne}

Kalinowski S., Uwagi dotyczące systematyki części szczególnej kodeksu karnego, s. 6 (Archiwum Akt Nowych w Warszawie, Ministerstwo Sprawiedliwości, sygn. 285/1941).

Pismo Sekretarza Episkopatu Polski biskupa Zygmunta Choromańskiego z dnia 9 maja 1963 r. do ministra sprawiedliwości Mariana Rybickiego w sprawie uwag do projektu kodeksu karnego, s. 2 (Archiwum Akt Nowych, Ministerstwo Sprawiedliwości, sygn. 564).

\section{Akty prawne}

Dekret z dnia 5 sierpnia 1949 r. o ochronie wolności sumienia i wyznania (Dz.U z 1949 r. $\mathrm{Nr} 45$ poz. 334).

Ustawa z dnia 21 stycznia 1958 r. o wzmożeniu ochrony mienia społecznego przed szkodami wynikającymi z przestępstwa (Dz.U z 1958 r. Nr 4 poz. 11).

61 L. Tyszkiewicz, Projekt kodeksu karnego z 1963..., s. 733.

62 Uchwała w sprawie projektu kodeksu karnego, „Prawo i Życie” 1963, nr 14, s. 1-2.

63 Szerzej zob. L. Tyszkiewicz, Projekt kodeksu karnego z 1963..., s. 727-731. 


\section{Literatura}

Berman H.J., Principles of Soviet Criminal Law, „Yale Law Journal” 1947, t. 56, s. 803-836, https://digitalcommons.law.yale.edu/ylj/vol56/iss5/2S (dostęp: 12.11.2019).

Friszke A., Jan Olszewski, [w:] Słownik polityków polskich XX wieku, red. P. Hauser, S. Żerka, Wydawnictwo Poznańskie, Poznań 1998, s. 253-255.

Goździcki E., Dyskutujemy nad proj. kk - Czy to logiczne?, „Wieczór” 1963, nr 44, s. 4.

Jankowski M., Przed publiczna dyskusja. Nad projektem kodeksu karnego, „Słowo Ludu” 1963, nr 73, s. 3.

Kochanowski J., Redukcja odpowiedzialności karnej: analiza i ocena założeń Kodeksu karnego z 1997 r. na tle innych polskich kodyfikacji karnych, C. H. Beck, Warszawa 2000.

Kodeks karny republik sowieckich, przeł. R. Łemkin, T. Kochanowicz, przy współudz.

L. Dworzaka, Z. Papierkowskiego, R. Piotrowskiego, wstęp J. Makarewicz, Księgarnia F. Hoesicka, Warszawa 1927.

Kodeks karny w ogniu dyskusji, „Polityka” 1963, nr 13, s. 4.

Kolczyński J., Projekt kodeksu karnego. Sześć pytań, „Prawo i Życie” 1963, nr 2, s. 1.

Krok naprzód czy wstecz?, „Głos Wielkopolski” 1963, nr 59, s. 3-4.

Lityński A., O prawie i sq̨dach początków Polski Ludowej, Temida 2, Białystok 1999.

Nowicz A., Stosunki Kościót-państwo w Polsce 1944-1956 (szkic zagadnienia), Głosy, Poznań 1984.

Olszewski J., K.k. i fantazja, „Nowa Kultura” 1963, nr 11, s. 3.

Olszewski J., Projekt nowy - treść stara, „Po prostu” 1956, nr 22, s. 2.

Olszewski J., Rozprawa z metoda, „Prawo i Życie” 1963, nr 4, s. 3.

Olszewski J., Zasady kodeksu i logika życia, „Prawo i Życie” 1963, nr 3, s. 1.

Pławski S., Walka Makarewicza o praworządność, „Państwo i Prawo” 1966, z. 2, s. 239.

Podsiadło W., Nad projektem kodeksu karnego (2) - paragrafy i życie, „Głos Szczeciński” 1963, nr 86, s. 3.

Projekt kodeksu karnego, Wydawnictwo Prawnicze, Warszawa 1963.

Projekt nowego kodeksu karnego. Postulat zniesienia kary dożywotniego więzienia, „Gazeta Krakowska” 1963, nr 16, s. 2.

Projekt nowego kodeksu karnego wchodzi pod publiczna dyskusje, „Trybuna Ludu” 1963, nr 18, s. 3.

Reperowicz S., Obywatel w cieniu paragrafów, „Żołnierz Wolności” 1963, nr 61, s. 3.

Rozpoczyna się publiczna dyskusja nad projektem nowego kodeksu karnego, „Express Wieczorny" 1963, nr 15, s. 1-2.

Szerer M., Punkty wyjścia, „Życie Warszawy” 1962, nr 290, s. 3.

Szerer M., Z części szczególnej sprawy szczególnie ważne, „Życie Warszawy” 1962, nr 295, s. 3.

Tyszkiewicz L., Projekt kodeksu karnego $z 1963$ roku na tle ewolucji polskiego prawa karnego $w$ XX wieku, [w:] O prawie i jego dziejach ksieggi dwie. Studia ofiarowane profesorowi Adamowi Lityńskiemu w czterdziestopięciolecie pracy naukowej i siedemdziesięciolecie urodzin, ks. II, red. M. Mikołajczyk, J. Ciągwa, P. Fiedorczyk, A. Stawarska-Rippel, T. Adamczyk, A. Drogoń, W. Organiściak, K. Kuźmicz, Wydawnictwo Uniwersytetu w Białymstoku, Białystok-Katowice 2010, s. 726-727.

Uchwała w sprawie projektu kodeksu karnego, „Prawo i Życie” 1963, nr 14, s. 1-2. 
Weiser A., Bezkarność przekupstwa w projekcie kodeksu karnego, „Głos Robotniczy” 1963, nr 115, s. 3.

Wielka kariera małej książeczki, „Nowa Kultura” 1963, nr 9, s. 2.

\section{Inne}

„Prawnik w czasach bezprawia”. Dyskusja po filmie o Janie Olszewskim, https://portalblogpress. blogspot.com/2017/09/21-sierpnia-gosciem-klubu-ronina-bya.html (dostęp: 19.11.2019). 